\title{
Penerapan Model Eliciting Activities (MEAs) dalam Pembelajaran Matematika Materi Relasi Dan Fungsi
}

\author{
Melia Kartika $^{1 *}$, Cecil Hiltrimartin ${ }^{2}$ \\ ${ }^{1,2}$ Universitas Sriwijaya, Kota Palembang, Sumatera Selatan 30128, Indonesia \\ Pengiriman: 22 Juli 2019; Diterima: 23 Oktober 2019; Publikasi: 30 Oktober 2019 \\ DOI: https://doi.org/10.31629/jg.v4i2.1347
}

\begin{abstract}
Abstrak
Penelitian ini merupakan penelitian deskriptif yang bertujuan untuk mengetahui aktivitas belajar siswa saat diterapkan pendekatan MEAs dan hasil belajar siswa setelah diterapkan pembelajaran MEAs materi relasi dan fungsi. Subjek penelitian ini adalah siswa kelas VIII D SMP Negeri 1 Indralaya Utara yang berjumlah 32 orang siswa. Data dikumpulkan menggunakan observasi dan tes dan di analisis secara deskriptif. Hasil penelitian menunjukkan keterlaksanaan kegiatan belajar siswa pada penerapan pembelajaran dengan pendekatan MEAs termasuk dalam kategori baik. Dari hasil pembelajaran didapat 29\% siswa termasuk dalam kategori sangat aktif, $19 \%$ siswa termasuk dalam kategori aktif dan $26 \%$ siswa terkategori cukup aktif sedangkan hasil belajar siswa dikategorikan cukup baik dimana 7\% siswa tergolong sangat baik, 33\% siswa tergolong ke dalam kategori baik dan $40 \%$ siswa tergolong cukup baik, dengan nilai rata-rata 66,1 .
\end{abstract}

Kata kunci: MEAs; aktivitas siswa; hasil belajar

\begin{abstract}
This study is the descriptive research that aims to determine student learning activities when applied MEAs approach and learning outcomes after applied MEAs with subject relation and function. The subjects were students of class VIIID junior high school number 1 Indralaya Utara, amounting to 32 students. The data were collected using observation dan test and analyzed descriptively. The research result to show implementation of student learning on MEAs approach included in the good category. From result learning get $29 \%$ students included in the very active category, $19 \%$ students included in active category and $26 \%$ students included in quite active category while students learning outcomes included pretty good when 7\% students included in very good category, 33\% students included in good category and $40 \%$ students included in pretty good category, with an average value is 66,1 .
\end{abstract}

Keywords: MEAs; students' activities; learning outcomes

\section{Pendahuluan}

Salah satu bidang studi yang memiliki peranan penting dalam kehidupan sehari-hari adalah matematika meskipun tidak semua permasalahan bersifat matematis namun matematika memiliki peranan penting untuk menjawab permasalahan karena matematika menuntut seseorang atau peserta didik memiliki beberapa kemampuan yang nantinya kemampuan itulah yang akan digunakan untuk menyelesaikan permasalahan. Berdasarkan Undang-Undang nomor 20 Tahun 2003 tentang 


\section{JURNAL GANTANG. Oktober 2019; IV(2): 161 - 168 \\ p-ISSN. 2503-0671 \\ e-ISSN. 2548-5547}

sistem pendidikan nasional menyatakan bahwa kurikulum pendidikan dasar hingga menengah wajib memuat beberapa mata pelajaran salah satunya matematika.

Sesuai tujuan pembelajaran matematika yang dimuat di dalam Permendiknas Nomor 22 Tahun 2006 yaitu agar siswa mampu 1) Memahami konsep matematika, menjelaskan keterkaitan antar konsep atau algoritma secara luwes,akurat, efisien dan tepat dalam pemecahan masalah 2) Menggunakan Penalaran pada pola dan sifat, melakukan manipulasi matematika dalam membuat generalisasi, menyusun bukti atau menjelaskan gagasan dan pernyataan matematika 3) Memecahkan Masalah yang meliputi kemampuan memahami masalah, merancang model matematika, menyelesaikan model dan menafsirkan solusi yang diperoleh 4) Mengkomunikasikan gagasan dengan simbol, tabel, diagram, atau media lain untuk memperjelas keadaan atau masalah 5) Memiliki sikap menghargai kegunaan matematika dalam kehidupan, yaitu memiliki rasa ingin tahu, perhatian, dan minat dalam mempelajari matematika, serta sikap ulet dan percaya diri dalam pemecahan masalah. Berdasarkan uraian diatas dapat diketahui bahwa matematika merupakan hal yang sangat penting dan sudah seharusnya mendapat perhatian lebih.

Namun fakta yang terjadi, dalam dunia pendidikan Indonesia, matematika yang dianggap penting belum menunjukkan kondisi yang memuaskan. Inti permasalahan dalam pendidikan matematika di Indonesia yang ditunjukkan oleh rendahnya prestasi siswa baik dalam skala nasional maupun internasional yaitu rendahnya mutu pendidikan (Zulkardi, 2005). Hal ini dapat dilihat berdasarkan hasil studi PISA tahun 2003 Indonesia pada posisi 38 dari 40 negara, tahun 2006 pada posisi 50 dari 57 negara, tahun 2009 pada posisi 61 dari 65 negara, tahun 2012 pada posisi 64 dari 65 negara dan 2015 menempatkan Indonesia pada posisi 63 dari 70 negara (OECD, 2016). Adapun menurut (OECD, 2013) hampir $80 \%$ siswa Indonesia berada pada level 1 dan hanya tidak mencapai $25 \%$ siswa yang mencapai level 2 ke atas.

Menurut Ruseffendi (2006) proses pembelajaran matematika di sekolah, pada umumnya siswa mempelajari matematika hanya diberitahu oleh gurunya bukan melalui kegiatan eksplorasi. Sehingga pembelajaran matematika kurang melibatkan aktivitas siswa secara optimal. Karena siswa tidak dilibatkan secara optimal. Pembelajaran matematika yang disampaikan oleh guru dianggap siswa sebagai suatu aturan sehingga siswa cenderung lebih mahir mengerjakan soal rutin yang tidak menuntut siswa untuk menarik kesimpulan berdasarkan fakta dan prinsip yang sudah ada. Pembelajaran konvensional yang dilaksanakan tidak melibatkan siswa secara aktif dalam mendemonstrasikan sesuatu yang berhubungan dengan konsep yang akan dipelajari (Matematika, Materi, Ruang, \& Datar, 2015)

Relasi dan fungsi adalah salah satu materi pada pelajaran matematika yang ada di tingkat Sekolah Menengah Pertama. Seperti yang dimuat di dalam buku fungsi merupakan salah satu konsep penting dalam matematika. Dengan mengenali fungsi atau hubungan fungsional antar unsur-unsur matematika, dapat lebih mudah memahami suatu permasalahan dan menyelesaikannya (Kemendikbud, 2017). Serupa dengan permasalahan pembelajaran matematika pada umumnya, yaitu siswa cenderung tidak bisa mengaitkan konsep yang terkandung pada materi relasi dan fungsi yang dipelajarinya (Di, Man, \& Aceh, 2017). Padahal materi relasi dan fungsi merupakan salah satu materi yang ada terapannya di dalam situasi nyata. Sesuai dengan tujuan pembelajaran matematika menurut Kurikulum 2013 adalah siswa dituntut untuk mampu dan terampil dalam memecahkan masalah dan mengaitkan konsep-konsep matematika dalam kehidupan sehari-hari (Kemendikbud, 2013).

Oleh sebab itu diperlukan suatu model pembelajaran yang melibatkan siswa secara aktif sehingga siswa dituntut untuk memahami suatu permasalahan sehingga capaian matematika 
siswa lebih baik. Sejalan dengan tuntutan kurikulum 2013 dimana siswa harus aktif terutama dalam memecahkan persoalan nyata dalam proses pembelajaran.

Salah satu pendekatan yang melibatkan siswa secara aktif yaitu Model Eliciting Activities (MEAs). MEAs adalah kegiatan yantg mengarahkan siswa pada situasi nyata melalui kelompok kecil tim kerja belajar yang beranggotakan 3-5 orang untuk menyelesaikan masalah dunia nyata (Hamilton, Lesh, Lester, \& Brilleslyper, 2008). Terdapat enam prinsip di dalam MEAs (Hamilton et al., 2008) yang dapat mengarahkan siswa untuk menyelesaikan permasalahan terkait situasi nyata. MEAs memberi peluang yang sangat besar kepada siswa untuk mengeksplorasi pengetahuannya dalam belajar matematika, diharapkan dapat membuat siswa mengubah pandangannya bahwa matematika sebagai pelajaran yang tidak sulit dan siswa sebenarnya mampu mempelajari matematika (Hanifah, 2016). Dengan menggunakan MEAs proses belajar siswa menjadi lebih bermakna dengan menghubungkan konsep yang dipelajari dengan konsep yang sudah dikenalnya serta menekankan siswa untuk belajar secara aktif.

Berdasarkan uraian diatas, tingkat keaktifan siswa masih sangat kurang dan rendahnya kemampuan siswa untuk mengaitkan konsep matematika yang berdampak pada hasil belajar siswa pada materi khususnya relasi dan fungsi maka dilakukanlah penelitian dengan menerapkan MEAs yang menurut penelitian terdahulu dapat mengeksplorasi pengetahuannya. Maka dari itu penelitian bertujuan untuk melihat aktivitas dan hasil belajar siswa setelah diterapkannya. Dengan demikian tulisan ini memberikan informasi bagaimana model ini diterapkan khususnya untuk materi relasi dan fungsi.

\section{Metode Penelitian}

Jenis penelitian ini adalah penelitian deskriptif yang bertujuan untuk melihat penerapan pendekatan MEAs yang ditunjukkan dari aktivitas siswa dan hasil belajar saat proses pembelajaran menggunakan pendekatan MEAs di kelas VIII D. Subjek dalam penelitian ini adalah siswa kelas VIII D SMP Negeri 1 Indralaya Utara dengan kemampuan yang heterogen. Variabel penelitian ini adalah aktivitas belajar siswa saat proses pembelajaran matematika dengan menggunakan pendekatan MEAs dan hasil belajar siswa dalam pembelajaran matematika setelah menggunakan pendekatan MEAs. Aktivitas belajar siswa didefinisikan secara operasional yaitu kegiatan yang dilakukan siswa selama pembelajaran matematika saat diterapkan MEAs. Hasil belajar siswa dalam pembelajaran matematika dlihat dari kemampuan siswa dalam mengerjakan atau menyelesaikan soal materi relasi dan fungsi setelah diterapkan MEAs. Hasil belajar siswa dalam penelitian ini diukur dari satu kali tes akhir setelah diterapkan MEAs

Teknik pengumpulan data yang digunakan adalah observasi dan tes. Observasi dilakukan untuk melihat aktivitas belajar siswa pada saat berlangsungnya pembelajaran matematika saat diterapkan pendekatan MEAs. Alat pengunpulan data yang digunakan adalah lembar observasi. Pengumpulan data dilakukan oleh 3 orang sebagai observer. Observer mengisi lembar observasi berdasarkan pengamatan langsung pada individu siswa masing-masing kelompok selama proses pembelajaran. Lembar observasi memuat 6 indikator yang masingmasing terbagi lagi menjadi beberapa deksriptor yang dikembangkan berdasarkan 6 prinsip MEAs dan tahapannya yaitu 1) memahami masalah dan mengkontruksi sendiri pengetahuannya 2) mengungkapkan dan mendokumentasikan proses berpikir dalam solusi 3) bekerja sama dalam kelompok 4) menanggapi dan bertanya 5) berpartisipasi selama proses pembelajaran 6) membandingkan solusi antar kelompok. Tes bertujuan untuk mengukur hasil belajar siswa dalam pembelajaran matematika materi relasi dan fungsi. Tes terdiri dari dua soal pemodelan matematika bentuk uraian.

Analisis data observasi dilakukan dengan cara memberikan skor pada data lembar observasi yang telah didapat. Adapun tahapan 
JURNAL GANTANG. Oktober 2019; IV(2): 161 - 168

p-ISSN. 2503-0671

e-ISSN. 2548-5547

pemberian skor yaitu: 1) observer memberikan tanda $(\sqrt{ })$ pada setiap deskriptor yang muncul pada lembar observasi 2) setelah data didapatkan kemudian dianalisis per-pertemuan dengan cara menghitung jumlah deskriptor yang muncul pada siswa selanjutnya akan dikelompokkan sesuai kategori berdasarkan Tabel 1.

Tabel 1.

Kategori aktivitas siswa

\begin{tabular}{cc}
\hline Nilai & Kategori \\
\hline $86-100$ & Sangat Aktif \\
$71-85$ & Aktif \\
$56-70$ & Cukup Aktif \\
$41-55$ & Kurang Aktif \\
$0-40$ & Tidak Aktif \\
\hline
\end{tabular}

Analisis data tes dilakukan dengan cara memberi skor pada masing-masing soal yang dikerjakan siswa berdasarkan pedoman penskoran yang telah dibuat. Selanjutnya, hasil tes siswa dikelompokkan sesuai dengan kategori pencapaian hasil belajar siswa pada materi relasi dan fungsi berdasarkan Tabel 2.

Tabel 2.

Kategori pencapaian hasil belajar siswa

\begin{tabular}{cc}
\hline Nilai & Kategori \\
\hline $86-100$ & Sangat Baik \\
$71-85$ & Baik \\
$56-70$ & Cukup \\
$41-55$ & Kurang \\
$0-40$ & Sangat Kurang \\
\hline
\end{tabular}

\section{Hasil dan Pembahasan}

Pembelajaran dengan pendekatan MEAs dilaksanakan menggunakan beberapa instrumen penelitian. Adapun instrumen penelitian yang digunakan ialah berupa Rencana Pelaksanaan Pembelajaran (RPP), Lembar Kerja Peserta Didik (LKPD), soal tes dan lembar observasi. Sebelum digunakan, instrumen penelitian yang telah divalidasi kepada 2 orang dosen pendidikan matematika sebagai validator.

Pelaksanaan pembelajaran dengan pendekatan MEAs dilaksanakan selama 3 pertemuan. Pada pertemuan pertama, materi yang diajarkan ialah relasi. Pertemuan kedua yang diajarkan ialah fungsi. Hasil observasi aktivitas siswa yang diperoleh dari dua pertemuan tersebut disajikan pada tabel 3 dan tabel 4 berikut ini.

Tabel 3.

Aktivitas siswa secara keseluruhan

\begin{tabular}{cccc}
\hline $\begin{array}{c}\text { Interval } \\
\text { skor }\end{array}$ & $\begin{array}{c}\text { Banyak } \\
\text { siswa }\end{array}$ & Persentase & Kategori \\
\hline $86-100$ & 9 & $29 \%$ & Sangat aktif \\
\hline $71-85$ & 6 & $19 \%$ & Aktif \\
\hline $56-70$ & 8 & $26 \%$ & Cukup aktif \\
\hline $41-55$ & 2 & $6 \%$ & Kurang aktif \\
\hline $0-40$ & 6 & $19 \%$ & Tidak aktif \\
\hline Jumlah & $\mathbf{3 1}$ & $100 \%$ & \\
\hline
\end{tabular}

Tabel 4.

Rekapitulasi aktivitas siswa per-indikator

\begin{tabular}{|c|c|c|c|c|c|}
\hline \multirow{2}{*}{ No } & \multirow{2}{*}{ Indikator } & \multirow{2}{*}{ Deskriptor } & \multicolumn{3}{|c|}{ Persentase $(\%)$} \\
\hline & & & $\mathbf{A}_{1}$ & $\mathbf{A}_{2}$ & $\overline{\mathbf{A}}$ \\
\hline \multirow{4}{*}{1} & \multirow{4}{*}{$\begin{array}{l}\text { Memahami masalah dan } \\
\text { mengkonstruksi sendiri } \\
\text { pengetahuan }\end{array}$} & $\begin{array}{l}\text { Siswa terlibat aktif dalam memahami masalah yang ada di } \\
\text { LKPD }\end{array}$ & 81 & 87 & \multirow{4}{*}{80} \\
\hline & & $\begin{array}{l}\text { Siswa mengalami proses konstruksi pengetahuannya dengan } \\
\text { sendiri }\end{array}$ & 74 & 71 & \\
\hline & & $\begin{array}{l}\text { Berusaha mencari informasi yang diperlukan untuk } \\
\text { memecahkan masalah yang ada di LKPD }\end{array}$ & 87 & 90 & \\
\hline & & Merancang permasalahan kedalam model matematika & 71 & 77 & \\
\hline 2 & $\begin{array}{l}\text { Mengungkapkan dan } \\
\text { mendokumentasikan } \\
\text { proses berpikir dalam } \\
\text { solusi }\end{array}$ & $\begin{array}{l}\text { Siswa berusaha untuk menuliskan solusi permasalahan yang } \\
\text { telah mereka rancang menggunakan model matematika }\end{array}$ & 42 & 61 & 52 \\
\hline 3 & Bekerja sama dalam & Siswa ikut serta dalam mendiskusikan LKPD & 90 & 90 & 85 \\
\hline
\end{tabular}


Kartika \& Hiltrimartin: Penerapan Model Eliciting Activities...(18)

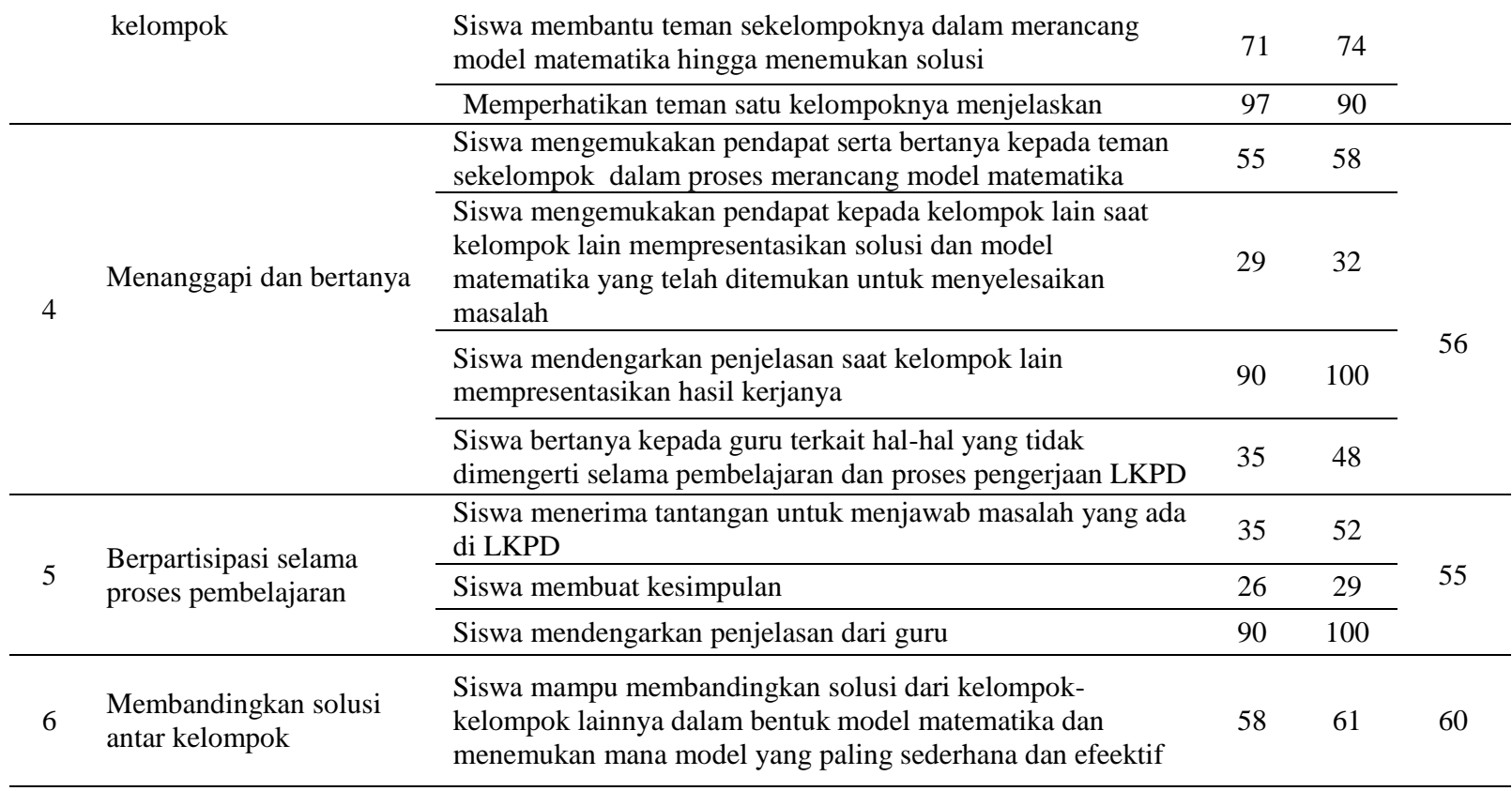

Sebanyak $48 \%$ siswa kelas VIII D SMP Negeri 1 Indralaya Utara dalam kategori aktif dengan rincian 29\% sangat aktif dan 19\% aktif sementara 26\% dikatakan cukup aktif dan $25 \%$ lagi sisanya berada di kategori kurang dan tidak aktif. Jika ditinjau dari pergerakan skor aktivitas pada tiap indikator selama 2 pertemuan terus mengalami kenaikan. Ini menandakan bahwa siswa antusias dan mulai terbiasa dalam menjalani proses pembelajaran matematika dengan pendekatan MEAs. Pembahasan tiap-tiap indikator aktivitas belajar siswa dalam komponen pada pembelajaran matematika dengan pendekatan MEAs sebagai berikut:

a) Memahami masalah dan mengkontruksi sendiri pengetahuannya

Dalam penelitian ini, langkah kegiatan pembelajaran MEAs yang pertama yaitu mengidentifikasi dan menyederhanakan situasi masalah ditinjau melalui indikator memahami dan mengkontruksi sendiri pengetahuannya yang dikembangkan berdasarkan 6 prinsip MEAs yang kemudian dipecah lagi menjadi 4 deskriptor. Indikator ini meninjau siswa dalam proses memahami masalah yang terdapat dalam LKPD. Mulai dari keterlibatan aktif siswa dalam kelompoknya untuk memahami masalah, membangun pengetahuan yang siswa miliki hingga usaha untuk mencari informasi agar dapat memecahkan permassalahan hingga nantinya siswa dapat mulai merancang permasalahan ke dalam model matematika. Hal ini sesuai dengan yang dungkapkan dalam penelitian Permana (Hanifah, 2015) menjelaskan bahwa MEAs memberi peluang yang sangat besar kepada siswa untuk mengeksplorasi pengetahuannya dalam belajar matematika, diharapkan dapat membuat siswa mengubah pendangannya bahwa matematika sebagai pelajaran yang tidak sulit dan siswa sebenarnya mampu mempelajari matematika. Proses belajar siswa dengan menggunakan MEAs menjadi bermakna karena dia dapat menghubungkan konsep yang dipelajari dengan konsep yang sudah dikenalnya serta menekankan siswa untuk belajar secara aktif. Dari hasil observasi di peroleh bahwa $80 \%$ siswa menjalankan aktivitas ini. Prinsip MEAs yang dikembangkan pada indikator ini yaitu prinsip kontruksi dan realitas.

b) Mengungkapkan dan mendokumentasikan proses berpikir dalam solusi

Selama proses pembelajaran MEAs berlangsung siswa dibiarkan untuk mengekplor pengetahuan di dalam kelompoknya masingmasing. Dalam proses diskusi kelompok, 


\section{JURNAL GANTANG. Oktober 2019; IV(2): 161 - 168 \\ p-ISSN. 2503-0671 \\ e-ISSN. 2548-5547}

masing-masing siswa berusaha merancang model matematika untuk memecahkan permasalahan yang diberikan oleh guru/peneliti melalui LKPD. Hingga pada akhirnya siswa akan menuliskan solusi permasalahan yang telah mereka rancang melalui model matematika. Namun dalam proses pembelajaran MEAs yang sifatnya berkelompok dengan kemampuan heterogen kebanyakan aktivitas ini hanya di dominasi oleh siswa tertentu saja. Hal ini disebabkan karena tidak setiap siswa terbiasa dan dapat merubah permasalahan kedalam model matematika. Waktu pembelajaran menggunakan MEAs yang dilakukan penelitu pun terhitung singkat, sedangkan tidak semua siswa memiliki daya pikir yang cepat. Indikator ini masuk kedalam tahapan pembelajaran MEAs yaitu membangun model matematis, mentransformasikan dan menyelesaikan model matematika .Berdasarkan observasi hanya $52 \%$ siswa saja yang melakukan aktivitas ini. Prinsip MEAs yang dikembangkan pada indikator ini yaitu prinsip self assessment dan dokumentasi.

c) Bekerja sama dalam kelompok

Selama proses pembelajaran berlangsung, siswa berdiskusi di dalam kelompoknya masing-masing, banyak kegiatan yang dilakukan siswa karena akan ada banyak pendapat yang dikeluarkan masing-masing individu. Siswa membantu teman sekelompoknya merancang model, memperhatikan teman satu kelompoknya menjelaskan hingga mengemukakan pendapat. Berdasarkan observasi $85 \%$ siswa melakukan aktivitas ini.

d) Menanggapi dan bertanya

Dalam penelitian ini, tahapan pembelajaran MEAs yang ada pada indikator ini yaitu mengidentifikasi model dimana siswa mempresentasikan solusi dan model matematika yang telah mereka temukan pada kelompok masing-masing untuk menyelesaikan masalah. Sementara kelompok lain mendengarkan penjelasan kelompok yang presentasi dan mengomentari jika ada solusi yang bebeda. Pada indikator ini tidak semua siswa terlibat karena masih banyak siswa yang malu untuk mengemukakan pendapatnya sehingga berdasarkan observasi hanya 56\% saja siswa yang melakukan aktivitas ini. Prinsip MEAs yang dikembangkan yaitu prinsip reusability dan berbagi kemampuan.

e) Berpartisipasi selama proses pembelajaran

Sebelum menutup proses pembelajaran MEAs peneliti memberikan pertanyaan tambahan/semacam tantangan untuk menjawab masalah yang dikembangkan dari LKPD, siswa menarik kesimpulan lalu mendengarkan penjelasan dari guru terkait hal-hal yang penting selama proses pembelajaran. Berdasarkan hasil observasi hanya 55\% saja siswa yang melakukan aktivitas ini karena tidak semua siswa memahami permasalahan yang ada pada LKPD sehingga siswa agak kesulitan untuk menerima tantangan dan menarik kesimpulan. Dorongan dan usaha dari peneliti kepada siswa agar siswa dapat lebih memahami masalah juga harus lebih ditingkatkan lagi.

f) Membandingkan solusi antar kelompok penulisan

Pada akhir pembelajaran siswa dapat membandingkan solusi dari kelompok-kelompok lainnya dalam bentuk model matematika serta menentukan model mana yang paling mudah untuk mereka mengerti berdasarkan penjelasan tambahan peneliti. Dalam aktivitas ini masih banyak siswa yang bingung dengan model matematika, kemampuan peneliti untuk mengarahkan siswan pada saat proses pembelajaran terjadi juga masih belum maksimal, beberapa siswa juga belum bisa menentukan model matematika sehingga berdasarkan observasi sebanyak $60 \%$ siswa yang melakukan aktivitas ini. Pada akhir pembelajaran ini prinsip MEAs yang di munculkan yaitu prinsip prototipe efektif.

Tes dilakukan pada pertemuan ketiga. Hasil tes yang di peroleh siswa disajikan pada tabel 5 . 
Tabel 5.

Hasil penilaian tes siswa

\begin{tabular}{cccc}
\hline $\begin{array}{c}\text { Interval } \\
\text { Skor }\end{array}$ & $\begin{array}{c}\text { Banyak } \\
\text { Siswa }\end{array}$ & Persentase & Kategori \\
\hline $86-100$ & 2 & $7 \%$ & Sangat \\
$71-85$ & 10 & $33 \%$ & Baik \\
$56-70$ & 12 & $40 \%$ & Baik \\
$41-55$ & 3 & $10 \%$ & $\begin{array}{c}\text { Cukup } \\
\text { Baik } \\
0-40\end{array}$ \\
& 3 & $10 \%$ & $\begin{array}{c}\text { Kurang } \\
\text { Sangat } \\
\text { kurang }\end{array}$ \\
& & & \\
\hline $\begin{array}{c}\text { Jumlah } \\
\text { Siswa }\end{array}$ & 30 & & \\
\hline $\begin{array}{c}\text { Rata- } \\
\text { rata }\end{array}$ & $\mathbf{6 6 , 1}$ & & $\begin{array}{c}\text { Cukup } \\
\text { baik }\end{array}$ \\
\hline
\end{tabular}

Menurut (Syah, 2012) bahwa untuk perkembangan kognitif siswa, tugas guru adalah menggunakan pendekatan pembelajaran yang memungkinkan siswa menggunakan strategi belajar yang berorientasi pada pemahaman yang mendalam terhadap isi materi pelajaran. Sehingga, penggunaan LKPD sesuai untuk digunakan dalam proses pembelajaran matematika karena jika dilihat dari hasil rata-rata penilaian pengetahuan siswa kelas VIII D pada pembelajaran matematika dengan pendekatan MEAs sudah termasuk dalam kategori cukup baik yaitu 66,1 .

Berdasarkan hasil analisis tes, $10 \%$ siswa mendapapatkan nilai dengan kategori kurang dan $7 \%$ siswa mendapat nilai dengan kategori sangat kurang. Hal ini disebabkan karena siswa tersebut berada dalam kategori cukup selama proses pembelajaran sehingga pengetahuan/kognitif siswa tidak berkembang optimal. Sebagaimana yang dikatakan (Sutrisno, 2012) bahwa siswa yang aktif selama proses pembelajaran dapat mengembangkan potensi individu peserta didik secara optimal. Dari 2 soal yang diujikan, sebagian besar soal terjawab dengan baik oleh siswa terutama soal nomor 1 . Hanya ada $12 \%$ siswa saja yang tergolong kurang baik. Selain kurang aktif dalam pembelajaran matematika dengan pendekatan MEAs yang telah dilakukan, siswa tidak terbiasa mendapat soal pemodelan yang berbentuk konteks sehari-hari, karena diungkapkan jika siswa progressive mematematikakan aktivitasnya, maka siswa dapat menemukan matematika dibawah bimbingan gueru atau desain pembelajaran (Eksploratif, Merangsang, \& Belajar, 2003)

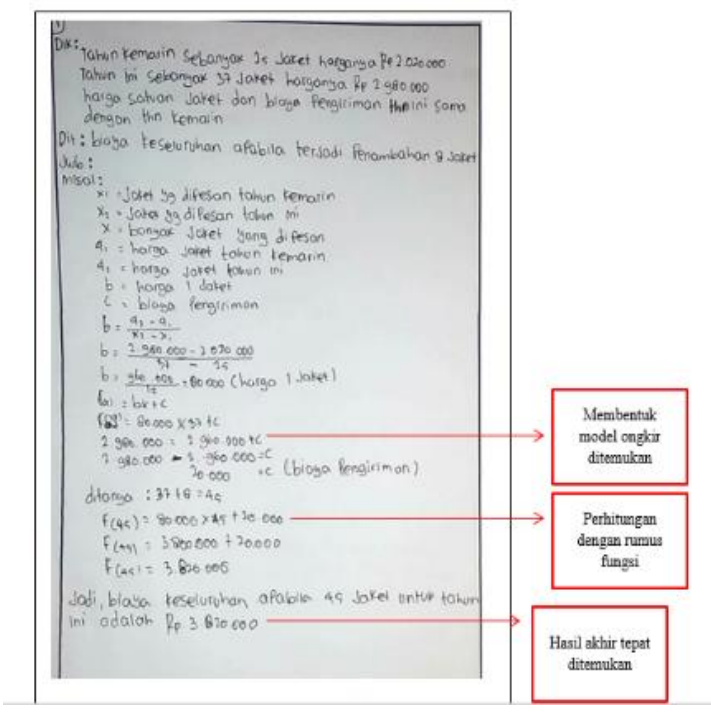

Gambar 1. Jawaban Siswa yang tepat pada soal tes

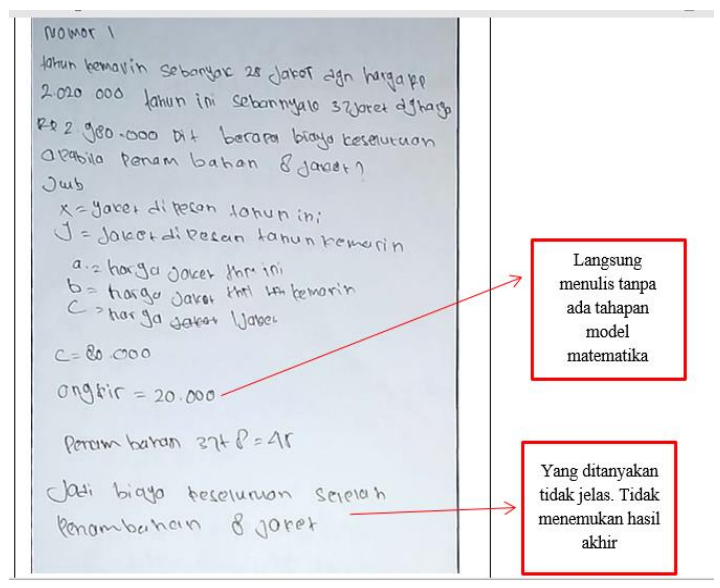

Gambar 2. Jawaban Siswa yang kurang tepat pada soal tes

\section{Kesimpulan}

Keterlaksanaan kegiatan belajar siswa pada penerapan pembelajaran dengan pendekatan MEAs yang ditinjau berdasarkan 6 indikator aktivitas siswa dimana untuk indikator memahami masalah dan mengkontruksi pengetahuan serta indikator bekerja sama dalam kelompok sudah lebih dari $80 \%$ ketercapaiannya sedangkan untuk indikator mengungkpakan dan mendokumentasikan proses berpikir dalam solusi, menanggapi dan bertanya, berpartisipasi selama proses pembelajaran serta membandingkan solusi antar kelompok mencapai lebih dari 50\% ketercapaiannya. Maka 
JURNAL GANTANG. Oktober 2019; IV(2): 161 - 168

p-ISSN. 2503-0671

e-ISSN. 2548-5547

dari itu dapat disimpulkan bahwa penerapan MEAs pada kelas VIII D SMP Negeri 1 Indralaya Utara termasuk dalam kategori baik. Dari hasil pembelajaran didapatkan $29 \%$ siswa termasuk dalam kategori sangat aktif, 19\% siswa termasuk dalam kategori aktif dan $26 \%$ siswa terkategori cukup aktif.

Hasil belajar siswa kelas VIII D SMP

Negeri 1 Indralaya Utara dalam pembelajaran matematika setelah diterapkan pendekatan MEAs dikategorikan cukup baik. Hal ini terlihat dari $7 \%$ siswa tergolong sangat baik, 33\% siswa tergolong ke dalam kategori baik dan $40 \%$ siswa tergolong cukup baik, dengan nilai rata-rata 66,1.

\section{Referensi}

Arikunto, S. (2010). Prosedur penelitian suatu pendekatan praktik. Jakarta: Rineka Cipta.

Di, F., Man, K. X., \& Aceh, B. (2017). Penerapan pendekatan saintifik pada materi relasi dan fungsi di kelas X MAN 3 Banda Aceh. Jurnal Peluang, 4(2).

Eksploratif, M., Merangsang, U., \& Belajar, S. (2003). Mengurangi rasa cemas belajar matematika dengan menampilkan matematika eksploratif untuk merangsang siswa belajar. 1-12.

Hamilton, E., Lesh, R., Lester, F., \& Brilleslyper, M. (2008). Model-eliciting activities (MEAs) as a bridge between engineering education research and mathematics education research. Advances in Engineering Education, 1, 1-25.

Hanifah, H. (2016). Penerapan pembelajaran Model Eliciting Activities (MEA) dengan pendekatan saintifik untuk meningkatkan kemampuan representasi matematis siswa. Kreano, Jurnal Matematika KreatifInovatif, $\quad 6(2), \quad 191$. https://doi.org/10.15294/kreano.v6i2.4694

Kemendikbud. (2017). Matematika kelas VIII Semester 1 Edisi Revisi 2017. Jakarta: Pusat Kurikulum dan Perbukuan, Balitbang.

Matematika, P., Materi, M., Ruang, B., \& Datar, S. (2015). Jurnal riset pendidikan matematika (Vol. 2).

OECD. (2018). PISA 2015 Results in Focus. Oecd. Retrieved from www.oecd.org/pisa

Ruseffendi. (1988). Pengantar kepada membantu guru mengembangkan kompetensinya dalam pengajaran matematika untuk meningkatkan CBSA: perkembangan kompetensi guru. 1988.

Sutrisno. (2012). Efektifitas pembelajaran dengan metode penemuan terbimbing terhadap pemahaman konsep matematis siswa. Jurnal Pendidikan Matematika FKIP Unila.

Syah, M. (2012). Psikologi Pembelajaran. Jakarta: Rajawali Pers.

Zulkardi. (2005). Pendidikan matematika di indonesia: beberapa permasalahan dan upaya penyelesaiannya. Pidato Pengukuhan Sebagai Guru Besar Tetap Pada FKIP UNSRI. Palembang. 